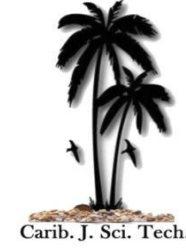

Authors \& Affiliation

Madhubabu Kasimala ${ }^{* 1,2}$,

Naomi Haileselassie ${ }^{2}$,

Lula Berhane ${ }^{2}$,

Bereket Abraha ${ }^{1}$,

Mogos Girmatsion ${ }^{3}$,

Romodan Mahmud ${ }^{4}$

${ }^{1}$ Department of Food Science and

Technology, Hamelmalo

Agricultural College, Anseba Region, Eritrea.

${ }^{2}$ Department of Marine Food and Biotechnology, Massawa College of Marine Science and Technology, Eritrea

${ }^{3}$ Department of Food Science and Engineering, School of Food

Science and Technology, Jiangnan

University, Wuxi, Peoples Republic of China

${ }^{4}$ Faculty of Food Technology and

Engineering, Saint Petersburg

National University of

information, Technologies,

Mechanics and Optics, Russia

Corresponding Author

Madhubabu Kasimala

Contact *Email id: madhu.lucky09@gmail.com

Received $7^{\text {th }}$ Dec' 2021

Accepted 24 $4^{\text {th }}$ Dec' 2021

(C) 2021. The Authors. Published under Caribbean Journal of Science and Technology

\section{Formulation and Nutritional Evaluation of Instant Diet for Children Fortified with Inshore Lizardfish (Synodus foetens)}

\begin{abstract}
The limited resources and inappropriate knowledge on effective utilization of available resources like fisheries in Eritrea have been resulting in severe malnutrition, especially among children. Dura Milk Kebkebe (DMK) - a traditional weaning food - is one of the improved weaning foods used as a food supplement for infants and children in addition to breastfeeding. A highly nutritive instant diet with maize and carrot fortified with fish powder from inshore Lizardfish has been prepared to aim to ensure the availability of low-cost weaning food in Eritrea. The nutritional composition of developed food contained proteins $19.50 \pm 1.58 \mathrm{~g}$, carbohydrates $52.50 \pm 3.15 \mathrm{~g}$, fats $6.03 \pm 2.19 \mathrm{~g}$, fiber $4.84 \pm 1.15 \mathrm{~g}$, and ash $3.26 \pm 0.98$ per $100 \mathrm{~g}$ of dry weight. The fatty acid profile of the developed weaning food has shown $1.71 \pm 1.11 \mathrm{~g}$ of polyunsaturated fatty acids, $2.26 \pm 0.05 \mathrm{~g}$ of monounsaturated fatty acids $2.06 \pm 1.51$ of saturated fatty acids per $100 \mathrm{~g}$ of sample with a potential nutritional value which was found better than DMK. The microbiological analysis of the weaning food has also shown within the recommended level of ISO food standards. Finally, it is learned that the developed weaning food was nutritious, microbiologically safe, and has gained acceptance from the consumers at organoleptic attributes. Due to the paucity of appropriate weaning food in developing countries like Eritrea, this product can be a good alternative to minimize malnutrition.
\end{abstract}

Keywords: Inshore lizardfish (Synodus foetens); microbiological parameter; proximate composition; sensory evaluation; weaning food.

\section{Introduction}

Protein Energy Malnutrition is one of the serious public health problems in all zones of Eritrea. A similar pattern of high rates of under-nutrition with no significant seasonal variations has been reported in a survey performed from 2001 to $2010^{1}$. In spite of this, inappropriate feeding practices of infants and young children are the most serious obstacles to maintaining adequate nutritional status and contribute to elevating malnutrition in most developing countries like Eritrea. The prevalence of stunting increased from $43 \%$ in 2002 to $50 \%$ in 2010 reflecting an overall increase in chronic malnutrition particularly among children aged of $6-12$ months ${ }^{2,3}$. 
Among the children of age group below five years, fifteen percent are suffering from severe acute malnutrition, and this malnutrition is aggravated by inadequate health care, shortage of food due to market instability, insufficient food grains in the country ${ }^{4}$.

Most children in developing countries such as sub-Saharan Africa and Southeast Asia are conversely affected by lack of food or inadequate supply of balanced nutrients due to poverty and poor nutritional knowledge ${ }^{5}$. Feeding infants from six months of cereals, pulses, cooked and mashed vegetables, carrots, and fish along with breastfeeding will improve the micronutrient status ${ }^{6}$. The weight of the infant triples within the first year, then slower; while the weight of the first year will be doubled by the age of five years. Meantime, the length of the child will be increased and continue till teenage. For proper growth of the body, a child needs an adequate amount of macronutrients such as protein, fats, carbohydrates, and micronutrients such as minerals and vitamins ${ }^{7}$

(Table 1).

Table1: Nutritional Requirement of Infants and Young Children

\begin{tabular}{|c|c|c|c|c|c|c|}
\hline Age $(\text { Years })^{\mathrm{a}}$ & Weight $(\mathrm{kg})^{\mathrm{a}}$ & Energy $(\mathrm{kcal})^{\mathrm{a}}$ & Protein $(\mathrm{g})^{\mathrm{a}}$ & Fat $(\mathrm{g})$ & Carbohydrate (g) & Fiber $(g)^{d}$ \\
\hline $0-1 / 2$ & 5.4 & 585 & 10 & $30^{\mathrm{b}}$ & $60^{\mathrm{b}}$ & \multirow{6}{*}{10} \\
\hline $1 / 2-1$ & 8.8 & 960 & 14 & $30^{\mathrm{b}}$ & $95^{\mathrm{b}}$ & \\
\hline $1-3$ & 11.9 & 1250 & 14 & $35^{\mathrm{a}}$ & $156^{\mathrm{c}}$ & \\
\hline $3-5$ & 15.9 & 1510 & 18 & $42^{\mathrm{a}}$ & $188^{\mathrm{c}}$ & \\
\hline $5-7$ & 19.6 & 1710 & 20 & $48^{\mathrm{a}}$ & $213^{\mathrm{c}}$ & \\
\hline $7-10$ & 25.9 & 1880 & 26 & $52^{a}$ & $235^{\mathrm{c}}$ & \\
\hline
\end{tabular}

${ }^{a}$ Ministry of health guidelines $(2013)^{8}$, State of Eritrea; ${ }^{b}$ Wardlaw and Smith ${ }^{7} ;{ }^{c}$ Calculated from reference intake (50\%) of energy required per day ${ }^{9}$; adequate intake ${ }^{9}$

In Eritrea, Dura Milk Kebkebe (DMK) is the only weaning food prepared at household by mixing cereal such as maize, wheat, barley, and rice with the available pulses. The composition of the ingredients varies at every household depending on the available grains in the local market and the economic status of the family. The typical weaning food among the populations with a high prevalence of malnutrition, in the case of infants and young children, consists predominantly of a starch-rich staple with incomplete proteins with little or no animal-source food. Protein from animal sources like fish provides the highest quality foods due to the completeness of easily digestible proteins ${ }^{10}$. A few studies have reported that the incorporation of fish meat or fish powder or fish protein concentrate into starch-based materials produces nutritious products that were acceptable by consumers $^{11}$.

Eritrea has long coast of the Red Sea with a high population of fishery resources within hundred kilometers from the coastline which accounts for $73 \%$ implies the comparative advantage in the marine sector $^{12}$. According to National Fisheries Corporation records, the total catches of fishery by foreign vessels are 6587.062 tons in 2019 , from which 1201.175 tons were discarded. Inshore lizardfish (S. foetens) is one of the underutilized soft bottom demersal fish often caught as shrimp by-catch ${ }^{13}$ which has high nutritive values accounts for $18.22 \%$ of the total catch. The consumption of lizardfish by the local community is negligible due to inappropriate knowledge in value added processing ${ }^{14}$. Therefore, the production of edible fish protein powder from discarding fish could be an important protein source for direct human consumption. Fish protein powder is a dried fish protein with complete nutritional content in which proteins are highly concentrated and is an excellent source of easily digestible amino acids ${ }^{11}$. Effective methods for processing, development of value-added products from underutilized fish, and promotion of their nutritional values play an important role to minimize the malnutrition problems of the country and it is also an important strategy to reduce industrial waste which is economically essential ${ }^{15}$.

\section{Material and Methods}

\section{Sample collection}

The Inshore lizardfish (S. foetens) samples were collected from the Eritrean coast of the Red Sea at the vicinity of Dahlak Archipelago in the month of November. Initially, the fish was stored in ice (1:1 ratio), then on landing, they were transported within 5 
- 6 hours to Food Processing Laboratory, Massawa College of Marine Science and Technology. The maize (Zea mays L.) and carrots (Daucus carota L.), Wheat (species of Triticum L), Chickpea (Cicer arietinum L.), and groundnut (Arachis hypogaea L.) were purchased from the local markets of Massawa. All the materials were transported to Food Processing Laboratory for further processing.

\section{Preparation of fish meal powder}

The fish meal powder was prepared by the method described by Balachandran, (2012) ${ }^{16}$ with slight modifications. The fish samples were washed several times under tap water, weighed, and beheaded. The gut was cleaned and blood was washed, the meat was separated by using a fishbone meat separator. The minced meat was cooked for one hour at $100^{\circ} \mathrm{C}$ to coagulate the proteins and release the fat. The cooked fish meat was pressed to remove the fat and water content, then dried in an oven for 12 hours at $60^{\circ} \mathrm{C}$ to reduce the moisture content. Then, the hot sample was ground into a fine powder and sieved to get a powder of 550 $\mu \mathrm{m}$ particle size. Finally, the fish powder was packed in low-density polythene bags and sealed to avoid any contamination.

\section{Preparation of maize powder}

The yellow maize (Z. mays- local cultivar) grains were soaked in water for 12 hours with a ratio $1: 4$, and then allowed for six days for germination to improve the nutritional value and also reduce the antinutrients such as phytate, trypsin inhibitors, and haemagglutinins ${ }^{17}$. The sprouted maize was washed and then dried in an oven at $100^{\circ} \mathrm{C}$ for 18 hours. The dried maize was ground and sieved using $550 \mu \mathrm{m}$ mesh; then the flour was packed in low-density polyethylene bags and hermetically sealed.

\section{Preparation of carrot powder}

The fresh and healthy carrots (D. carota L.) were selected and peeled, washed, and chopped into small pieces. They were blanched for two minutes to deactivate the enzymes that can be palatable ${ }^{18}$. The blanched pieces were dried in an oven for 12 hours at $90^{\circ} \mathrm{C}$, and then ground into powder, sieved using $550 \mu \mathrm{m}$ mesh to get fine carrot powder. The powder was packed in low-density polyethylene bags and hermetically sealed.

\section{Formulation of DMK and weaning food mix}

In Eritrea, every household prepares DMK using various cereals and pulses available in the local market which are seasonal and are imported from neighbouring countries. So, the composition of DMK changes depending on the availability of grains in the market and the social-economic status of the family. However, the DMK used in this study was prepared by mixing $70 \%$ wheat (species of Triticum L.), $15 \%$ of Chickpea (C. arietinum L.), and $15 \%$ of groundnut (A. hypogaea $\mathrm{L}$ ). This composition has been widely practiced in the majority of the population of the country.

The weaning food was prepared with the primary intention of balancing protein since protein is vital for body development and growth in infants and young children. The formula has been adopted from Kuna et al., (2013) ${ }^{19}$ with slight modification. In the development of the food mixture $15 \%$ of fish powder, $15 \%$ of carrot powder, and $70 \%$ of germinated maize powder were used. The $15 \%$ of fish powder was selected by considering the fact that, the average amount of protein in lizardfish powder has been measured as 85 to $90 \%{ }^{20}$. While the average protein requirement for infants with an average body weight of $7.1 \mathrm{~kg}$ is $1.75 \mathrm{~g} / \mathrm{kg} / \mathrm{day}$ and for children below 10 years with an average body weight of $18.32 \mathrm{kgs}$ is 1.00 $\mathrm{g} / \mathrm{kg} / \mathrm{day}^{21}$.

\section{Nutritional analysis of the product mix}

Proximate composition of the prepared food mixture was determined as crude protein was estimated by semi-micro Kjeldahl method (AOAC, $2000)^{22}$, the protein content was calculated by multiplying the total nitrogen content with 6.25 . The ash content was determined by using a muffle furnace at $570^{\circ} \mathrm{C}$ and moisture content was measured by using a conventional oven method (AOAC, 2000) ${ }^{22}$. The carbohydrate content was measured at $315 \mathrm{~nm}$ using a double beam spectrophotometer (VWR - model 6300) and concentrated Sulphuric acid (Ammar et al., $2015)^{23}$, crude lipid (Bligh and Dyer,1959) ${ }^{24}$, The crude fiber was determined by using HennenbergStohmann method (AOAC, 1995) ${ }^{25}$. Saturated and unsaturated fatty acids were quantified by capillary Gas Chromatography-Mass Spectrometry (GC/MS), Thermo Triple-Q GCMSMS. Briefly, the FAME was analyzed by injecting $1 \mu \mathrm{L}$ (30:1split ratio) into GC- 
MS equipped with capillary column (30 m x $0.25 \mathrm{~mm}$ $\mathrm{x} 0.25 \mu)^{22}$.

\section{Microbiological analysis}

Microbiological parameters of the samples were analyzed at the Quality Control Laboratory, Ministry of Marine Resources in Massawa, Eritrea by ISO methods ${ }^{26,27}$. The microbiological analysis included total plate count (TPC), total fungal count (TFC), total coli forms (TC), Staphylococcus aureus, anaerobic sulphate reducing bacteria, Salmonella sps., and Vibrio parahaemolyticus.

Analysis for enumeration of microorganisms for TPC was done using the pour plate technique, and total fungal count (TFC) was done by the spread plate technique at $30^{\circ} \mathrm{C}$ (ISO 4833:2003). The ISO method (4831:2006) was used to enumerate the TC count at $44^{\circ} \mathrm{C}$ using the multiple tube technique, while anaerobic sulphate reducing bacteria were enumerated by ISO 7937:2004. Multiple tube technique was also used to enumerate beta-glucuronidase-positive E. coli (ISO 16649-3:2001), while coagulase-positive $S$. aureus was enumerated by spread plate technique (ISO 6888-1:2003). Salmonella sps. was detected using ISO (6579:2002) and $V$. parahaemolyticus was detected by ISO (8914-1990) method.

\section{Sensory evaluation of the weaning foods}

The sensory evaluation of the new weaning food was conducted in Ghindae Referral Hospital, Northern Red Sea region, Eritrea. Fourteen infants and twenty-five young children of below 5 years age along with their mothers were inquired to assess the samples in uncooked and cooked form of the developed foods. All panelists were briefed to make understand the sensory attributes before evaluation. The panelists were asked to rinse their mouths after tasting each product. The quality attributes appearance, color, odor, texture, flavor and overall acceptability of the prepared weaning food were evaluated in comparison with the DMK powder. For the cooked product taste was evaluated in addition to above mentioned sensory attributes using a five-point hedonic scale ranging from 'Like extremely' to 'Dislike extremely' ${ }^{28,29}$.

\section{Statistical analysis}

Statistical data was analyzed by program (SPSS 20.0) for Windows.

\section{Results and Discussion}

\section{Raw material parameters}

The mean length of inshore lizardfish $(S$. foetens) was measured $22.86 \pm 2.15 \mathrm{~cm}$, while the weight was measured as $91.13 \pm 3.18 \mathrm{~g}$. The amount of minced meat from the whole fish was $50 \%$ and the dried fish powder was $12.5 \%$. The minced meat and dry powder are in harmony with the results of Ratnakumar and Pancharaju (2018) who have reported $50 \%$ of minced meat and $15.6 \%$ of dried fish powder from lizardfish species (Saurida tumbil) collected from Thoothukudi, India ${ }^{20}$. While Jitesh et al., (2011) have reported $42.22 \%$ of minced meat yielded from the $S$. tumbil collected from Gujarat coast of India ${ }^{30}$. It is established that, the yield parameters of fish vary with environmental condition of ecosystem, nutrients availability, season, age and maturity of the fish ${ }^{31}$.

\section{Nutritional parameters}

The nutritional composition of both DMK and fish powder fortified diet were given in the table 2. In this study, the moisture content of DMK reported $(7.6 \pm 1.17 \%)$ was higher than fish powder formulation (4.6 \pm 1.04$)$. Similar results have been reported in the biscuits prepared by incorporation Chinese Sturgeon Fish Fillet Powder ${ }^{32}$. The moisture content is used as an indicator for the quality of cereal based products, which should be $3-8 \% \%^{5}$; the moisture content below $10 \%$ is acceptable for microbial safety of fishery products $^{33}$. Both DMK and fish powder diets contain an acceptable range of moisture.

The crude protein content was found $14.01 \pm 2.01$ and $19.50 \pm 1.58$ in DMK and fish product formulation respectively. According to $\mathrm{FAO} / \mathrm{WHO}$ (1982) minimum protein content of $15 \%$ is required in food for proper growth and maintenance of the body ${ }^{29}$. The Codex Alimentarius Standards for weaning foods reports (1994) recommended the range of protein should be from 14.52 to $37.70 \%$ for maximum complementation of amino acids in foods ${ }^{5}$. Thus, both DMK and fish powder formulations satisfy the protein demands of weaning foods for infants and children recommended by the ministry of health, the government of Eritrea ${ }^{8}$. However, the ingredients used in DMK formulation are deficient of certain essential amino acids such as, chickpea is deficient of sulphur containing amino acids Methionine and Cystine ${ }^{34}$, 
groundnut and wheat are deficient of Lysine, Threonine, and sulphour containing amino acids ${ }^{35}$. On the other hand, fish is a good source of easily digestible protein with all essential amino acids ${ }^{36}$ indicating new formulated fish food is reported more suitable for better growth of the body.

The total fat content of the DMK was found $3.18 \pm 1.27 \%$ and $6.03 \pm 2.19 \%$ in formulated fish powder diet. In DMK, the groundnut is a major source of fat, which contains a high amount of linoleic acid and oleic acid ${ }^{37}$. The literatures have shown $1.13^{20}-$ $1.89 \%$ of total fat in lizardfish (S. tumbil) and classified lizardfish as lean fish ${ }^{30}$. The total lipids content in fish varies significantly with age, maturity, geographical differences, and species variation ${ }^{38}$. It could be reasons that, maize has contributed to the high fat content in fish powder fortified diet, which contains $4.06 \%$ of fats ${ }^{29}$. The fat content of formulated foods was recommended to have less than $10 \%$ for better shelf-life stability by minimizing the possibilities of oxidative rancidity ${ }^{5}$. Both diets have reported less than the recommended level of fat indicates the shelf-life stability of the products. Maize is a good source of linoleic acid, while the fish is a good source of linolenic acid ${ }^{39}$ which has contributed to the amount of mono and polyunsaturated fatty acids in the fish powder diet. The fatty acids are essential for the physical properties of membranes including membrane-bound enzymes, antigenic recognition, signal transduction, and receptor activity ${ }^{40}$. At the same time, consumption of a high amount of saturated fatty acids will increase the blood cholesterol levels; therefore the fish powder diet is much better in connection to coronary health than the diet of DMK.

Table 2: Proximate Composition of DMK and Fish Powder Fortified Diet

\begin{tabular}{|l|c|c|}
\hline Nutritional parameters* & DMK & Fish powder fortified diet \\
\hline Moisture (\%) & $7.6 \pm 1.17$ & $4.6 \pm 1.04$ \\
\hline CP (\%) & $14.01 \pm 2.01$ & $19.50 \pm 1.58$ \\
\hline Total fat & $3.18 \pm 1.27$ & $6.03 \pm 2.19$ \\
\hline Saturated fatty acids (\%) & $2.17 \pm 0.98$ & $2.06 \pm 1.51$ \\
\hline MUFA (\%) & $1.11 \pm 0.05$ & $2.26 \pm 0.05$ \\
\hline PUFA (\%) & ND & $1.71 \pm 1.11$ \\
\hline CHO (\%) & $54.30 \pm 2.75$ & $52.50 \pm 3.15$ \\
\hline Ash (\%) & $2.6 \pm 1.12$ & $3.26 \pm 0.98$ \\
\hline Fiber (\%) & $14.57 \pm 1.98$ & $4.84 \pm 1.15$ \\
\hline Energy (Kcal)/100g & 302.76 & 396.27 \\
\hline
\end{tabular}

*CP: Crude Protein; CHO: Carbohydrates; MUFA: Mono-unsaturated fatty acids; PUFA: Poly-unsaturated fatty acids; ND: Not detectable.

The carbohydrate content of DMK is $54.30 \pm 2.75$ in which wheat is the major source of carbohydrates, whereas the formulated fish powder diet prepared by mixing germinated maize as a source of carbohydrates contains $52.50 \pm 3.15$, whereas maize is a good source of carbohydrates, containing $70 \%$ carbohydrates ${ }^{29}$. The low amount of carbohydrates in both diets can be attributed to the milling ${ }^{32}$ process and the germination processing in which some amounts of carbohydrates are lost in the milling process and/or consumed for the sprouting process. Both DMK and formulated fish powder diet have satisfied the minimum requirements of carbohydrates (41.13 to $73.79 \mathrm{~g} / 100 \mathrm{~g}$ ) as per the Codex Alimentarius Standards (1994) ${ }^{5}$.

The fiber content of the formulated diet was $14.57 \pm 1.98$ in DMK and 4.84 \pm 1.15 in the fish powder diet. The high fiber content of DMK is attributed to the raw materials used such as wheat, chick pea and groundnut, which are good sources of fiber, while carrot $(2.1 \%)^{41}$, maize $(1.42 \%)^{5}$ and fish $(0.0$ $0.28 \%)^{5,31}$ contains a comparatively low amount of fiber. The low fiber content in fish powder fortified diet can be attributed to germination of maize, which could decrease the fiber content due to enzymatic changes during the sprouting process. As a thumb rule, fiber is an essential dietary constituent that play role in preventing constipation, colon cancer, obesity, and cardiovascular diseases. However, high dietary fiber content impairs the absorption of Zinc, Iron, and Calcium $^{39}$. Hence, moderate fiber diets are suitable for weaning foods so fish fortified diet has advantageous than DMK. 
The ash content of DMK was found $2.6 \pm 1.12 \%$ and the fish powder diet was $3.26 \pm 0.98$. Fish is a good source of minerals such as phosphorus, magnesium, iron, zinc, and iodine ${ }^{31}$, the high ash content in the fish powder diet is an indicator of the presence of more minerals in the food product. Though the Codex Alimentarius Standards do not specify the ash content for weaning foods ${ }^{5}$, it is stated that both products are considered to be a good diet with respect to ash content.

The total caloric contents of DMK and fish powder fortified diets are 302.76 and $396.27 \mathrm{kcal} / 100 \mathrm{~g}$ respectively. As a matter of fact, the calorific value of diets is attributed to their carbohydrate, protein, and fat content. The energy density of both DMK and fish fortified diets are lower than the minimum energy (483.9 Kcal/100g) recommended in the Codex Alimentarius Standards for weaning foods 5 . Therefore, to provide the required energy, approximately $160 \mathrm{~g}$ of DMK and 122g of fish fortified diet should be given per day to satisfy the total energy requirement recommended by Codex standards.

\section{Microbiological parameters}

The microbial analysis of both diets was ascertained through assessment of microbial parameters including total plate count (cfu/g), total coliforms, (MPN/g), E. coli (MPN/g), Staphylococcus aureus (cfu/g), Anaerobic sulphate Reducing bacteria at $35^{\circ} \mathrm{C}$ (cfu/g), Salmonellaspp. (Occurrence in $25 \mathrm{~g}$ ), $V$. parahaemolyticus (occurrence in $25 \mathrm{~g}$ ) and total fungal count (cfu/g) which are indicated in table 3. All the microbial parameters in both products were shown within the acceptable limits of WHA/FAO standards ${ }^{26}$, 27. Since both the products comply with microbial safety guidelines, finally it is said that they are absolutely fit for consumption immediately after cooking.

Table 3: Microbiological analysis of DMK and fish powder fortified diet

\begin{tabular}{|l|c|c|c|}
\hline \multicolumn{1}{|c|}{ Parameter } & \multirow{2}{*}{ Standard } & \multicolumn{2}{c|}{ Results of analysis } \\
\cline { 3 - 4 } & & DMK & Fish fortified diet \\
\hline Total plate count $(\mathrm{cfu} / \mathrm{g})$ & $5 \times 10^{4}$ & $2.1 \times 10^{3}$ & $2.8 \times 10^{3}$ \\
\hline Total coliforms at $37^{0} \mathrm{c}(\mathrm{MPN} / \mathrm{g})$ & 5 & $<3$ & $<3$ \\
\hline E.coil $(\mathrm{MPN} / \mathrm{g})$ & 5 & $<3$ & $<3$ \\
\hline Staphylococcus aureus $(\mathrm{cfu} / \mathrm{g})$ & $<2 \times 10^{2}$ & $1.5 \times 10^{2}$ & $1.0 \times 10^{2}$ \\
\hline Anaerobic sulfate Reducing bacteria at $35^{0} \mathrm{C}(\mathrm{cfu} / \mathrm{g})$ & $<5 \times 10^{6}$ & 10 & 10 \\
\hline Salmonella species $($ occurrence/25g) & Absent in 25 & Absent in 25 & Absent in 25 \\
\hline Vibrio parahaemolyticus $($ occurrence/25g) & $<10^{3}$ & Absent in 25 & Absent in 25 \\
\hline Total fungal count $(\mathrm{cfu} / \mathrm{g})$ & $<2 \times 10^{3}$ & $2.3 \times 10^{2}$ & $2 \times 10^{2}$ \\
\hline
\end{tabular}

\section{Sensory evaluation}

The cooked and uncooked products of fish-based diet were reported highest score in all attributes than DMK (Figure 1).
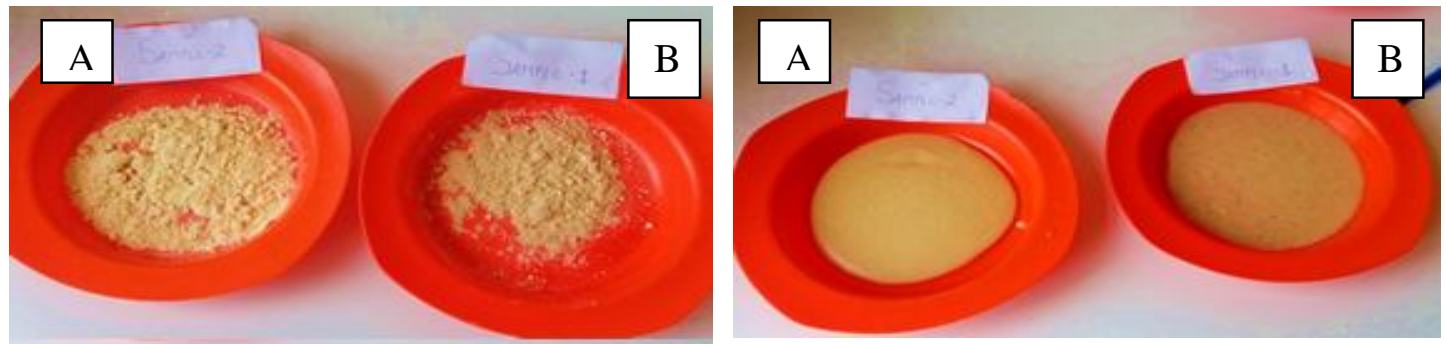

Figure. 1 Samples of DMK (A) and Fish fortified diet (B) before cooking (left) and after cooking (right)

In the case of Appearance, both diets were shown significantly different, whereas colour and texture
Sensory analysis of both products in cooked and uncooked form was given in Table 4. registered statistically non-significant. Odour has shown significantly in uncooked however the overall 
acceptability recorded statistically non-significant. Taste attribute is shown significantly different in the cooked form of both diets. The cooked form fish diet has shown the highest acceptability by all the panellists, which indicates that the diet is a better source of nutrients with high consumers' acceptability.

Table 4. Sensory analysis of DMK and Fish fortified diet

\begin{tabular}{|c|c|c|c|c|c|c|}
\hline \multirow[b]{2}{*}{ Attributes } & \multicolumn{2}{|c|}{ Uncooked form } & \multirow[b]{2}{*}{$\begin{array}{c}\text { Sig. } \\
(\alpha=0.05)\end{array}$} & \multicolumn{2}{|c|}{ Cooked form } & \multirow[b]{2}{*}{$\begin{array}{c}\text { Sig. } \\
(\alpha=0.05)\end{array}$} \\
\hline & DMK & $\begin{array}{c}\text { Fish } \\
\text { powder diet }\end{array}$ & & DMK & $\begin{array}{c}\text { Fish powder } \\
\text { diet }\end{array}$ & \\
\hline Appearance & $3.45 \pm 0.42^{*}$ & $4.39 \pm 0.07$ & $\mathrm{~S}^{\#}$ & $3.39 \pm 0.27$ & $4.13 \pm 0.12$ & $\mathrm{~S}$ \\
\hline Colour & $2.35 \pm 0.26$ & $3.56 \pm 0.14$ & $\mathrm{NS}^{* *}$ & $3.73 \pm 0.12$ & $4.53 \pm 0.21$ & NS \\
\hline Odour & $3.45 \pm 0.27$ & $3.80 \pm 0.16$ & $\mathrm{~S}$ & $3.19 \pm 0.11$ & $4.48 \pm 0.18$ & $\mathrm{NS}$ \\
\hline Texture & $3.02 \pm 0.07$ & $3.82 \pm 0.14$ & $\mathrm{NS}$ & $3.64 \pm 0.13$ & $4.41 \pm 0.13$ & $\mathrm{NS}$ \\
\hline Taste & N/A & N/A & - & $4.18 \pm 0.08$ & $4.30 \pm 0.10$ & $\mathrm{~S}$ \\
\hline Overall acceptability & $3.32 \pm 0.21$ & $4.27 \pm 0.12$ & NS & $4.27 \pm 0.12$ & $4.38 \pm 0.18$ & $S$ \\
\hline
\end{tabular}

$*$ Mean \pm standard deviation; $\quad \# \mathrm{~S}=$ significant; $* * \mathrm{NS}=$ non=significant.

\section{Conclusion}

In this study, the results of both products were evaluated up to the level, recommended by Codex Alimentarius standards and the Ministry of Health, Government of Eritrea. All the raw materials used in the preparation of the fish powder diet were available in the local market at a low price and the diet was proved a better source of proteins and essential fatty acids, which are vital for child growth compared to DMK. At the same time, carrots were reported as a good source of carotenoids, which are precursors of vitamin $\mathrm{A}$, indicating that the newly formulated fish powder diet has additional health benefits. Thus, the nutritive value of the assessed formulated fish powder diet shows additional nourishment, thereby helping to reduce malnutrition among children. Overall, this study could contribute to the effective utilization of discarding fish species to augment food security in the country.

\section{Acknowledgements}

The authors are commemorating the departed colleague Mr. Pasience Pius Magoha, who had supervised the work partially and the care shared with the team.

\section{Conflict of interest}

The authors declare no conflict of interest

\section{References:}

1) MoH. "Ministry of Health Situation Analysis of the Health Sector" Eritrea, January, 2016
2) National Statistics Office, Eritrea Population and Health Survey, Asmara, Eritrea. 2013

3) Kelati, H.; Mengiste, B.; Alemayehu, T.; Damtew, B. Prevalence of Acute Malnutrition and its Associated Factors among Children aged 6-59 months in Mai-Aini Eritrean Refugees' Camp, Northern Ethiopia. J. Nutr. Food Sci. 2014, 5, 336. https://doi:10.4172/2155-9600.1000336.

4) Unicef. 2020. Eritrea Situation Report. Annual Humanitarian Situation Report: JanuaryDecember 2019.

5) Tiencheu, B.; Achidi, U.A.; Fossi, T.B.; Tenyang, N.; Ngongang, T.F.E.; Womeni, M.H. Formulation and Nutritional Evaluation of Instant Weaning Foods Processed from Maize (Zea mays), Pawpaw (Carica papaya), Red Beans (Phaseolus vulgaris) and Mackerel Fish Meal (Scomber scombrus). Amer. J. Food Sci. and Tech. 2016, 4, 149.

6) National guidelines on infant and young child feeding. 2004. Ministry of Human Resources Development, Government of India.

7) Wardlaw, M.G.; Smith, A.M. 2009. Contemporary Nutrition, $7^{\text {th }}$ edition, McGrow Hill, NY, USA. 725p.

8) MoH. "Eritrean operational guidelines on infant and young child feeding", Nutrition unit, Ministry of Health. 2013

9) EFSA. 2017. Overview on Dietary Reference Values for the EU population as derived by the EFSA Panel on Dietetic Products, Nutrition and Allergies

(NDA) 
https://www.efsa.europa.eu/sites/default/files/ assets/DRV_Summary_tables_jan_17.pdf

10) Campbell, W.W.; Barton, M.L.; CyrCampbell, D.; Davey, S.L.; Beard, J.L.; Parise, G.; Evans, W.J. Effects of an omnivorous diet compared with a lactoovovegetarian diet on resistance-training-induced changesin body composition and skeletal muscle in older men. Amer. J. Cli Nutr. 1999, 70, 1032.

11) Shaviklo, R.A. Development of fish protein powder as an ingredient for food applications: A review. J. Food. Sci. Tech. 2015, 52, 648. https://doi.org/10.1007/s13197-013-1042-7.

12) Teweldemedhin, M.Y. The fish industry in Eritrea: from comparative to competitive advantage. Afri. J. Agri. Res. 2008, 3, 327.

13) Chávez-López, R.; Rocha-Ramírez, A.; Álvarez, F.; Wetzer, R. (Isopoda, Cymothoidae) Parasitizing the Inshore Lizardfish, Synodus foetens (Linnaeus, 1766) On the Continental Shelf of Central Veracruz, Mexico. Crustaceana, 2005, 78, 865.

14) FAO. 2002. Food and Agricultural Organization of United Nations, Fishery country profile, FID/CP/ERI/Rev. 1.

15) Jaziri, A.A.; Shapawi, R.; Mokhtar, M.A.R.; Noordin, M.N.W.; Huda, A. Chemical Composition of Lizardfish Surimi By-product: Focus on Macro and Micro-minerals Contents. Curr. Res. Nutr. Food Sci. J. 2021, 9, 52.

16) Balachandran, K.K. 2012. Postharvest technology of fish and fish products, Daya publishing house, New Delhi, India.

17) Reddy, N.R.; Balakrishnan, C.V.; Salunkhe, D.K. Phytate phosphorus and mineral changes during germination and cooking of black gram (Phaseolus mungo) seeds. J. Food Sci. 1978, 43, 540.

18) Barrett, D.M.; Somogyi, L.; Ramaswamy, H. 2005. Processing Fruits Science and Technology, $2^{\text {nd }}$ ed., CRC Press, Florida, USA. ISBN: 0-8493-1478-X

19) Kuna, A.; Devi, L.N.; Kalpana, K. Utilization of Fish Powder in Ready-to-Eat Extruded Snacks. Fishery Tech. 2013, 50, 245.

20) Rathnakumar, K.; Pancharaja, N. Development of health mix from Lizardfish and its nutritional characteristics, Int. J. Curr. Micro. App. Sci.
2018, $7, \quad 3136 . \quad$ doi: https://doi.org/10.20546/ijcmas.2018.703.362.

21) Garlick, J.P. 2006. Protein and Energy Requirements in Infancy and Childhood. Nestlé Nutr Workshop Ser Pediatr Program, $58,39$.

22) AOAC. 2000. Official methods of analysis. In Association of Official Analytical Chemists (18 ${ }^{\text {th }}$ ed). Gaithersburg, MD (Ed.). Maryland. Pp. 1193

23) Ammar, A.A.; Asmeret, A.B.; Teamrat, A.G. A new method for rapid determination of carbohydrate and total carbon concentrations using UV spectrophotometry, Carbohydrate Polymers, 2013, 97, 253.

24) Bligh, E.G.; Dyer, W.J. A rapid method of total lipid extraction and purification. Can. J. Biochem. Phys. $1959 . \quad 37,911$. https://doi:10.1139/y59-099.

25) AOAC. 1995. Official Methods of Analysis of the Association of Analytical Chemists International, $16^{\text {th }}$ ed. Method 978.10, Washington DC, USA.

26) ISO 4833. 1991. General Guide Lines for the Enumeration of Microorganisms-Colony Count Technique at $30^{\circ} \mathrm{C}\left(2^{\text {nd }}\right.$ ed). Technical committee: ISO/TC 34/SC 9 Microbiology. Pp. 12 pp. Retrieved from https://www.iso.org/standard/10816.html.

27) Morton, R.D. 2001. Aerobic plate count. In: Downes, FP, Ito, K, editors. Compendium of methods for the microbiological examination of foods. $4^{\text {th }}$ ed. Washington (DC): American Public Health Association. Chapter 6. p. 63-67.

28) Amerine, M.A.; Pongborn, R.M.; Roessler, E.B. 1965. Principles of Sensory Evaluation of food. Academic press, New York, USA.

29) Amankwah, E.A.; Barimah, J.; Nuamah, A.K.M.; Oldham, J.H.; Nnaji, C.O. Formulation of Weaning Food from Fermented Maize, Rice, Soybean and Fishmeal. Pak. J. Nutr. 2009, 81747.

30) Jitesh, S.B.; Syed, Z.M.; Hitendra, P.L.; Ashok, D.R.; Anil, K.S.; Balakrishnan, G. Effect of egg albumen (protein additive) on surimi prepared from lizardfish (Saurida tumbil) during frozen storage. AACL Bioflux, 2011, 4, 306. 
31) Tsighe, N.; Wawire, M.; Bereket, A.; Karimi, S.; Wainaina, I. Physicochemical and microbiological characteristics of fresh Indian mackerel, spotted sardine and yellowtail scad, from Eritrea Red Sea waters. J. Food Comp. and Analy. 2018, 70, 98. https://doi.org/10.1016/j.jfca.2018.05.001.

32) Bereket, A.; Abdu, M.; Habtamu, A.; HabteMichael, H.; Wenshui, X.; Fang, Y. Production of Biscuit from Chinese Sturgeon Fish Fillet Powder (Acipeneser sinensis): A Snack Food for Children, J. Aqu. Food Prod. Tech. 2018. https://doi.org/10.1080/10498850.2018.1533906

33) Jeyasanta, K.I.; Aiyamperumal, V.; Patterson, J. Utilization of trash fish as edible fish powder and its quality characteristics and consumer acceptance. World J. Dairy Food Sci. 2013. 8, 01 .

https://doi:10.5829/idosi.wjdfs.2013.8.1.7123.

34) Iqbal, A.; Khalil, I.A.; Ateeq, N. Nutritional quality of important food legumes. Food Chem. 2006, 97, 331.

35) Eastwood, M. 2003. Principles of Human Nutrition, $2^{\text {nd }}$ ed, Blackwell publishing, UK, 680p. ISBN: 0-632-05811-0.
36) Hansen, A.E.; Haggard, M.E.; Boelsche, A.N.; Dam, D.J.; Wiese, H.F. Essential fatty acids in infant nutrition. III. Clinical manifestations of linoleic acid deficiency. J. Nutr. 1958, 66, 565.

37) Isleib, T.; Patte, H.; Sanders, T.; Hendrix, K.; Dean, L. Compositional and sensory comparison between normal and high oleic peanuts. J. Agric. Food Chem., 2006, 54: 179.

38) Nurnadia, A.A.; Azrina, A.; Amin, I. Proximate composition and energetic value of selected marine fish and shellfish from the West coast of Peninsular Malaysia. Int. Food Res. J. 2011, $18,137$.

39) Michaelsen, F.K.; Weaver, L.; Branca, F.; Robertson, A. 2003. Feeding and nutrition of infants and young children, WHO regional publication, European series no. 87. ISBN: 92 89013540.

40) Uauy, R.; Mena, P.; Valenzuela, A. Essential fatty acids as determinants of lipid requirements in infants, children and adults. Euro. J. Clin. Nutri. 1999, 53,Suppl 1, S66.

41) Roe, M.; Church, S.; Pinchen, H.; Finglas, P. Nutrient analysis of fruit and vegetables, Analytical report, 2013. http://www.dh.gov.uk/publications. 